\title{
THE EFFECT OF GIVING ALOE VERA GEL ON RATS WITH BACTERIA-INDUCED PERIODONTITIS
}

\author{
Muhamat Muhtar S. Abdurrohman*, Dhiya Almanda Fa'adiyah*, Rama Putranto*,Budi Soehartono*
}

* Fakultas Kedokteran Gigi UNISSULA

Correspondence : $\underline{\text { m.muhtar@unissula.ac.id }}$

Keywords:
Alkaline phosphatase, Aloe
vera, Periodontitis

\begin{abstract}
Background: Aloe vera (AV) contains a variety of characteristic antibiotic and anti-inflammatory components that have potential advantages for periodontal disease therapy. Diagnostic and prognostic markers of periodontal disease through the activity of alkaline phosphatase (ALP) in gingival crevicular fluid. This study was conducted to evaluate the effect of giving AV gel on alkaline phosphatase levels in rats with bacteria-induced periodontitis

Method: Thirty-six male Sprague dawley were healthy and active, weighing 170-200 grams, aged 2 months were distinguished into two groups: the control group of periodontitis given therapy Gel Metronidazole plus 25\% and AV gel $99.03 \%$ as a treatment group. Aloe vera gel is administered topically in gingival sulcus at a dose of $300 \mathrm{mg} / \mathrm{kg}$ of rat weight. Samples were taken from gingival sulcus liquid on days 1,2 and 3 using periopaper paper. Alkaline phosphatase levels are measured using a UV/Vis Spectrophotometer with a wavelength of $405 \mathrm{~nm}$. Variant analysis is used to compare ALP levels in different groups Result: There was significant difference in alkaline phosphatase levels between the control group and the treatment group ( $p>0.05)$. In Sprague dawley rats with periodontitis, there was a significant decrease in ALP levels on days 1,2 and 3 given Metronidazole gel plus 25\% therapy and AV gel $99.03 \%$. But the treatment group showed lower ALP levels than the control group
\end{abstract}

Conclusion: This study revealed that the use of AV gel locally has an effect and can be as an adjunct therapy for periodontitis

\section{PENDAHULUAN}

Periodontitis merupakan salah satu masalah utama kesehatan mulut yang mempengaruhi kesehatan tubuh secara keseluruhan dengan prevalensi kasus $70 \%$ dari jumlah populasi global. ${ }^{1}$ Penyakit inflamasi ini disebabkan oleh biofilm bakteri yang merusak jaringan penyangga gigi (ligamen periodontal, gingiva dan tulang alveolar) atau sering disebut jaringan periodonsium. ${ }^{2}$ Aktivitas inflamasi yang terjadi di jaringan periodonsium dapat ditentukan melalui kadar alkaline phosphatase (ALP) dalam cairan sulkus gingiva (GCF). ${ }^{3}$ Alkaline phosphatase adalah salah satu marker diagnostik pertama yang diidentifikasi dalam GCF dengan kadar lebih tinggi daripada di serum. ${ }^{4}$ Alkaline Phosphatase tersimpan dalam granul spesifik dan vesikula sekretori neutrofil yang akan sekresikan dan bermigrasi ke daerah inflamasi. Analisis ALP pada cairan sulkus gingiva merupakan pendekatan yang paling praktis untuk analisis biokimia dari respon host pada penyakit periodontal. ${ }^{5}$

Kadar ALP dapat diukur pada 0 jam sampai 14 hari dengan puncak kadar ALP pada hari ke 14 sebesar $56.75 \pm 11.50 \quad$ IU/L. ${ }^{4}$ Kenaikan kadar Alkaline Phosphatase secara signifikan pada cairan 
sulkus gingiva akan menyebabkan periodontitis hingga kehilangan gigi. ${ }^{1}$ Upaya untuk menurunkan kadar ALP tersebut dengan kontrol plak atau biofilm secara mekanis. ${ }^{6}$ Eleminasi biofilm subgingiva dan jaringan sekitar yang terinfeksi oleh patogen anaerobik, dilakukan dengan scaling dan root planing (SRP). ${ }^{7}$ Metode konvensional prosedur non-bedah,mechanical scaling/root planing (SRP) belum menjamin perbaikan penyakit periodonsium. Penggunaan terapi antibiotik sistemik untuk periodontitis masih terbatas, karena diperlukan dosis tinggi untuk mencapai konsentrasi yang tepat dari obat di dalam cairan sulkus gingiva, adanya resistensi bakteri, dan efek samping dari obat. ${ }^{5}$ Menurut penelitian, scaling dan root planing dikombinasikan dengan aloe vera sebagai terapi tambahan menghasilkan perbaikan yang signifikan pada periodontitis yang parah. ${ }^{8}$

Aloe vera mengandung vitamin, mineral, enzim, gula, anthroquinon atau komponen fenolik, lignin, saponin, sterol, asam amino dan asam salisilat. Antrokuinon setara dengan alkaloid, yaitu berperan sebagai analgesia dan memiliki sifat regenerasi jaringan, antibakteri, antivirus, dan antijamur. ${ }^{9}$ Oleh karena itu, penelitian ini bertujuan untuk menganalisis efek aloe vera pada tikus yang diinduksi periodontitis melalui kadar ALP pada cairan sulkus gingiva

\section{METODE PENELITIAN}

Desain penelitian ini adalah studi invitro dan dilakukan secara random selama 10 hari. Tiga puluh enam Sprague dawley jantan sehat dan aktif, berusia 2 bulan dengan berat 170-200 gram dibagi dalam 2 kelompok yaitu kelompok kontrol Ti-es Metronidazole gel plus 25\% dan gel Aloe Vera 99.03\% sebagai kelompok perlakuan. Tikus diinjeksi dengan bakteri Phropyromonas gingivalis sebanyak $0,02 \mathrm{ml}$ dengan konsentrasi $1 \times 10^{8} \mathrm{CFU}$ pada daerah sulkus gingiva gigi anterior rahang bawah dan diobservasi selama 7 hari. Ethical clearance diperoleh dari komite etik penelitian kesehatan (KEPK) No.159/B.1-KEPK/SAFKG/XII/2019.

Parameter klinis periodontitis pada model hewan coba diamati dan diukur baik sebelum dan setelah perlakuan, meliputi: warna gingiva, probing pocket depth, clinical attachment loss,sSulcus bleeding index. Pada hari ke-8 semua kelompok dilakukan scaling manual dan selanjutnya diaplikasikan Ti-es Metronidazole gel plus 25\% dan gel Aloe vera $99.03 \%$ dengan injeksi infiltrasi pada daerah sekitar sulkus gigi anterior rahang bawah. ${ }^{10}$

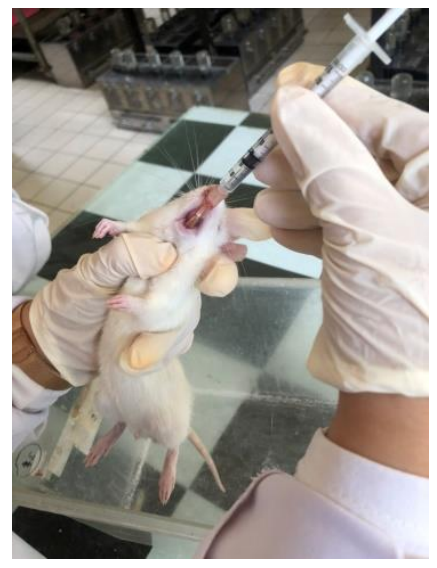

Gambar 1 injeksi infiltrasi bakteri Porphyromonas gingivalis intrasulkuler

Sampel GCF dikumpulkan dari setiap sampel pada hari ke-1, -2 dan -3 , setelah aplikasi gel dengan menggunakan periopaper strip yang dimasukkan kedalam poket dan dibiarkan selama 60 detik. Sampel didilusikan dengan penambahan $0,9 \% \mathrm{NaCl}$. Sampel kemudian dilakukan pengukuran kadar ALP menggunakan Spektrofotometer UV-Vis dengan panjang gelombang $405 \mathrm{~nm}$. 


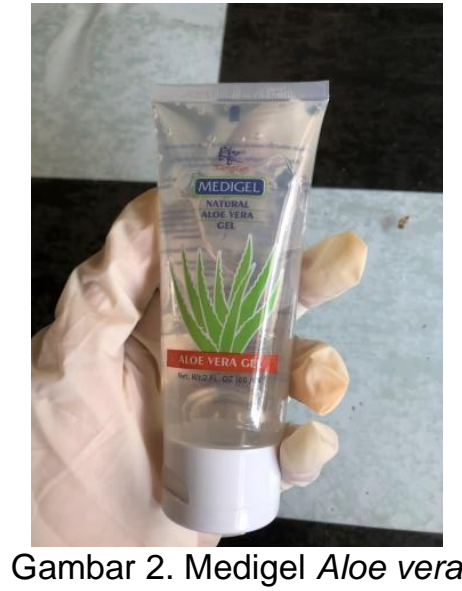

Gel lidah buaya (Aloe Vera) yang digunakan dalam penelitian ini adalah menggunakan gel Aloe vera fabricated yaitu medigel natural Aloe vera yang diproduksi oleh Kangzen Kenko yang berasal dari Bangkok, Thailand. Sediaan dalam produk ini berupa gel 99,03\% diekstrak dari Aloe Barbadensis dan $100 \%$ bebas Alloin.

Analisis statistik dilakukan dengan menggunakan SPSS versi 22, Independent t-test untuk membandingkan dua kelompok yang berbeda

\section{HASIL PENELITIAN}

Hasil pengukuran kadar ALP sebagai berikut:

Tabel 1. Rerata (u/L) dan standar deviasi kadar ALP pre dan post perlakuan

\begin{tabular}{lcccc}
\hline Group & $\mathrm{N}$ & $\mathrm{T}$ Time & Mean & $\mathrm{SD}$ \\
\hline Metronidazole & 18 & $\mathrm{~T}-7$ & 85.54 & 1.91 \\
\cline { 2 - 4 } gel plus 25\% & $\mathrm{T}+1$ & 66.39 & 3.60 \\
\cline { 2 - 4 } & & $\mathrm{T}+2$ & 57.28 & 3.54 \\
\cline { 2 - 4 } & $\mathrm{T}+3$ & 50.08 & 2.31 \\
\hline Gel Aloe Vera & 18 & $\mathrm{~T}-7$ & 84.85 & 2.51 \\
\cline { 2 - 4 } 99.03\% & $\mathrm{T}+1$ & 67.16 & 3.86 \\
\cline { 2 - 4 } & & $\mathrm{T}+2$ & 55.75 & 2.64 \\
\cline { 2 - 4 } & $\mathrm{T}+3$ & 50.92 & 2.38 \\
\hline
\end{tabular}

Berdasarkan tabel 1 rerata kadar ALP kelompok Metronidazole gel plus 25\% menunjukkan nilai tertinggi pada hari pertama diikuti hari kedua dan terendah hari ketiga, demikian pula pada kelompok gel Aloe Vera $99.03 \%$. Secara keseluruhan rerata kadar ALP pada kedua kelompok mengalami penurunan dari hari pertama sampai hari ketiga.

Hasil uji normalitas $p>0.05$, data normal dan uji homogenitas $p<0.05$, data tidak homogen. Hasil ini menunjukkan semua kelompok memiliki data yang terdistribusi normal, namun data tidak homogen.

Tabel 2. Hasil uji Friedman kontrol positif

\begin{tabular}{ccc}
\hline Kelompok & $\mathbf{P}$ & $\begin{array}{c}\text { Sig } \\
<\mathbf{0 . 0 5}\end{array}$ \\
\hline $\begin{array}{c}\text { Ti-es } \\
\begin{array}{c}\text { Metronidazole gel } \\
\text { plus 25\% }\end{array}\end{array}$ & 0.007 & $\mathrm{P}<0.05$ \\
\hline asil Uji Friedman, $\quad \mathrm{p}=0.007 \quad(\mathrm{p}<0.05)$
\end{tabular}
menunjukkan terdapat perbedaan yang signifikan pemberian Ti-es Metronidazole gel plus 25\% terhadap penurunan kadar ALP pada setiap harinya

Tabel 3. Hasil uji Pairwise Comparisons Ti-es Metronidazole gel plus 25\%

\begin{tabular}{ccc}
\hline Kelompok & waktu & $\begin{array}{c}\text { Rerata } \\
\text { penurunan } \\
\text { kadar ALP } \\
\text { (u/L) }\end{array}$ \\
\hline Ti-es & $\mathrm{T}+1$ & 19.14 \\
\cline { 2 - 3 } $\begin{array}{c}\text { Metronidazole } \\
\text { gel plus 25\% }\end{array}$ & $\mathrm{T}+2$ & 28.26 \\
\cline { 2 - 3 } & $\mathrm{T}+3$ & 35.45 \\
\hline
\end{tabular}

Uji Pairwise Comparisons pada tabel 3 . menunjukkan penurunan kadar ALP setiap harinya, mulai dari periodontitis sampai hari pertama pemberian Ti-es Metronidazole gel plus 25\% rerata sebesar $19.14 \mathrm{u} / \mathrm{L}$, penurunan kadar ALP saat periodontitis sampai hari kedua rerata sebesar $28.26 \mathrm{u} / \mathrm{L}$, dan penurunan kadar ALP saat periodontitis sampai hari ketiga rerata sebesar $35.45 \mathrm{u} / \mathrm{L}$.

Uji normalitas pada kelompok pemberian gel Aloe Vera hari 1 memiliki data yang tidak terditribusi normal, dan terdistribusi normal pada kelompok lain. Uji homogenitas $p>0.05$, data homogen. Hasil yang didapatkan menunjukkan data homogen, tetapi tidak terdistribusi normal.

Tabel 4. Hasil uji Friedman gel Aloe Vera 


\begin{tabular}{ccc}
\hline Kelompok & $\mathbf{P}$ & Sig $<0.05$ \\
\hline Gel Aloe Vera & 0.00 & $\mathrm{P}<0.05$ \\
\hline
\end{tabular}

Uji Friedman didapatkan $\mathrm{p}=0.00(\mathrm{p}<0.05)$ yang menunjukkan bahwa terdapat perbedaan yang signifikan pemberian gel Aloe Vera terhadap penurunan kadar ALP setiap harinya.

Tabel 5. Hasil uji Pairwise Comparisons gel Aloe Vera

\begin{tabular}{ccc}
\hline kelompok & waktu & $\begin{array}{c}\text { Rerata } \\
\text { penurunan } \\
\text { kadar ALP } \\
(\mathbf{u} / \mathbf{L})\end{array}$ \\
\hline Gel Aloe & & 17.6 \\
\cline { 2 - 3 } Vera & $\mathrm{T}+1$ & 29.10 \\
\cline { 2 - 3 } & $\mathrm{T}+2$ & 33.92 \\
\hline
\end{tabular}

Uji Pairwise Comparisons menunjukkan bahwa rerata perbedaan penurunan kadar ALP mulai dari periodontitis sampai hari ke-1 pemberian gel Aloe Vera sebesar $17.6 \mathrm{u} / \mathrm{L}$, penurunan kadar

\section{DISKUSI}

Terapi lokal pada penyakit periodontal dengan menggunakan terapi herbal banyak dikembangan diberbagai penelitian. ${ }^{11}$ Hasil penelitian Aloe vera yang diaplikasikan secara lokal/topikal berpengaruh terhadap penurunan kadar ALP cairan sulkus gingiva pada tikus periodontitis. Hasil uji statistik menunjukkan Ti-es Metronidazole gel plus 25\% pada hari ke-3 rerata sebesar (50.08 ( \pm 2.31$) \mathrm{u} / \mathrm{L})$ dan gel Aloe Vera sebesar (50.92 $( \pm 2.38) \mathrm{u} / \mathrm{L})$ sehingga tidak ada perbedaan yang signifikan antara aplikasi menggunakan Ti-es Metronidazole gel plus 25\% dan gel Aloe Vera. Selisih dan rerata penurunan kadar ALP tiap kelompok dua medikamen, dalam setiap harinya terdapat perbedaan penurunan yang signifikan. Pada kelompok Ti-es Metronidazole gel plus $25 \%$ didapatkan penurunan pada hari 1 sebesar $19.14 \mathrm{u} / \mathrm{L}$, diikuti dengan hari ke 2 sebesar
ALP hari ke-2 rerata sebesar $29.10 \mathrm{u} / \mathrm{L}$, dan penurunan kadar ALP hari ke-3 sebesar $33.92 \mathrm{u} / \mathrm{L}$

Tabel 6. Hasil uji korelasi Spearman

\begin{tabular}{cccc}
\hline korelasi & $\begin{array}{c}\text { Koefisien } \\
\text { korelasi }\end{array}$ & $\begin{array}{c}\text { Nilai } \\
(\mathbf{p}<\mathbf{0 . 0 5})\end{array}$ \\
\hline $\begin{array}{c}\text { Kadar ALP terhadap } \\
\text { gel Aloe Vera }\end{array}$ & -0.95 & 0.00 & \\
\hline Angka koefisien & korelasi & pada & tabel 6.
\end{tabular}

bernilai negatif yaitu -0.95 , yang berarti hubungan kedua variabel tersebut tidak searah, diartikan bahwa semakin lama pemberian gel Aloe Vera pada hewan coba yang mengalami periodontitis, maka akan semakin menurunkan kadar ALP. Nilai signifikan hubungan kedua variabel sebesar 0,00 $(p<0,05)$ maka dapat diartikan bahwa terdapat hubungan yang signifikan antara pemberian gel Aloe Vera setiap harinya dengan penurunan kadar ALP pada hewan coba yang mengalami periodontitis

$28.26 \mathrm{u} / \mathrm{L}$ dan hari ke 3 sebesar $35.45 \mathrm{u} / \mathrm{L}$. Begitu pula dengan kelompok gel Aloe Vera didapatkan pada hari 1 sebesar $17.6 \mathrm{u} / \mathrm{L}$ diikuti hari ke 2 sebesar $29.10 \mathrm{u} / \mathrm{L}$ dan hari ke 3 sebesar 33,92 u/L. Hal ini sejalan dengan penelitian Virdi (2012) bahwa Aloe vera yang diberikan per oral maupun topikal efektif untuk meningkatkan penyembuhan luka dengan meningkatkan suplai darah, yang hasilnya meningkatkan oksigenasi jaringan. ${ }^{11}$

Aloe vera memiliki banyak agen antiinflamasi seperti carboxypeptidase yang mampu menonaktifkan bradikinin sekitar $67 \%$ dan mengurangi rasa sakit serta memiliki sifat sintesis anti-prostaglandin yang baik dan senyawa penghambat oksidasi asam arakidonat, yang dapat mengurangi inflamasi. ${ }^{12}$ Aloe vera menghambat sekresi Prostaglandin E2 (PGE2) sehingga kadar ALP dapat menurun pada saat periodontitis. ${ }^{13}$ 
Distribusi ALP pada jaringan periodontal yang mengalami periodontitis seperti yang dipelajari oleh Carranza dan Cabrini, adalah bahwa ALP ditemukan dalam jumlah besar pada dinding lateral jaringan granulasi, dasar poket periodontal dan pada gingival fiber pada titik tersebut. Selain itu leukosit polimorfonuklear, bakteri dalam dental plak, osteoblas dan fibroblas adalah sumber utama ALP. ${ }^{3}$

Rasio ALP pada GCF terhadap serum berkisar antara 6:1 hingga 11:1, hal ini menunjukkan bahwa sintesis alkaline phosphatase oleh enzim lebih banyak diproduksi secara lokal. Rasio tersebut tidak ada hubungan yang signifikan antara total GCF-ALP dengan kadar ALP-plak dan analisis plak. ${ }^{3} \mathrm{Hal}$ ini menunjukkan kadar ALP yang normal berasal dari jaringan periodontal, maka peningkatan ALP pada penyakit periodontal menunjukkan reaksi metabolisme enzim terhadap perubahan jaringan yang disebabkan oleh inflamasi. ${ }^{14}$ Aktivitas ALP dapat diamati sebaik mungkin sebagai indikator inflamasi gingiva, metabolisme tulang dan jumlah enzim sangat meningkat ketika terjadi inflamasi. ${ }^{15}$

Peningkatan kadar ALP meningkat terutama pada periodontitis masuk fase early lesion. Fase ini akan terjadi 4-7 hari dan akan mencapai puncaknya pada 6-12 hari. ${ }^{16}$ Pada fase ini terjadi peningkatan jumlah neutrofil di jaringan ikat. Selain itu juga terlihat makrofag, limfosit, sel plasma, dan sel mast. ${ }^{17}$ Pendekatakan diagnosis pada periodontitis dapat dilakukan melalui 2 cara, yaitu dengan prosedur diagnosis klinis seperti berdasarkan parameter Bleeding On Probing (BOP), Clinical Attachment Levels (CAL) atau dengan analisa enzim yang terkandung dalam CSG seperti pengukuran kadar ALP, Lactate Dehydrogenase (LDH), Alanine Aminotrasnferases (ALT), Aspartate (AST), Creatine Kinase (CK), Achid Phosphatase (ACP), Gamma-glutamyl Transferase (GGT). ${ }^{18}$

\section{KESIMPULAN}

Aloe vera ge/ berefek pada tikus periodontitis yang diinduksi bakteri dengan melihat kadar Alkaline Phosphatase (ALP). Kadar ALP menurun setelah pemberian Aloe vera gel. Hal ini menunjukkan peran penting pemberian terapi lokal pada perawatan periodontitis seperti Aloe vera gel

\section{UCAPAN TERIMAKASIH}

Dengan selesainya penelitian ini, kami mengucapkan terima kasih kepada Dekan FKG Unissula, LPPM Unissula, Lab PAU Gadjah Mada yang telah memberikan support dalam pelaksanaan penelitian ini.

\section{DAFTAR PUSTAKA}

1. Soud P, Gupta HL, Kumar P, Sethi S, Yadav $\mathrm{N}$. Estimation and Comparison of Levels of Alkaline Phosphatase ( ALP ), Acid Phosphatase ( ACP ), Calcium ( $\mathrm{Ca}$ ) and Potassium ( $\mathrm{K}$ ) in Serum of Subjects with and Without Periodontal Disease (PD ). Int J Appl Dent Sci. 2015;1(4):90-93.

2. Amalina $\mathrm{R}$, Mahdalena M, Aditya G Differences in the salivary inorganic ions levels and salivary flow rate of the periodontitis and non-periodontitis patients. Padjadjaran J Dent. 2020;32(2):160-165. doi:10.24198/pjd.vol30no3.21201.

3. Yendluri Durga Bai, R A. Estimation of GCF Alkaline Phosphatase Levels in Health and Periodontal Disease - A Clinico Biochemical Study. Int J Contemp Med Res [IJCMR]. 2018;5(7):5-8.

doi:10.21276/ijcmr.2018.5.7.7.

4. Malhotra R, Grover V, Kapoor A, Kapur R. Alkaline phosphatase as a periodontal disease marker. Indian $J$ Dent Res. 2010;21(4):531-536. doi:10.4103/09709290.74209

5. Maschinen B, Investition A, Beschaffungen G, Ersatzbeschaffungen B, Mittelherkunft S. Relationship between bone-type alkaline phosphatase levels in gingival crevicular fluid and clinical parameters during supportive periodontal therapy. J Jpn Soc Periodontal. 2018.

6. Gupta S, Chhina S, Arora SA. A systematic review of biomarkers of gingival crevicular fluid: Their predictive role in diagnosis of periodontal disease status Journal of Oral Biology and Craniofacial Research A 
systematic review of biomarkers of gingival crevicular fl uid: Their pre. J Oral Biol Craniofacial Res. 2019;8(2):98-104. doi:10.1016/j.jobcr.2018.02.002.

7. Miani PK, Do Nascimento C, Sato S, Filho A V., Da Fonseca MJV, Pedrazzi V. In vivo evaluation of a metronidazole-containing gel for the adjuvant treatment of chronic periodontitis: Preliminary results. Eur J Clin Microbiol Infect Dis. 2012;31(7):1611-1618. doi:10.1007/s10096-011-1484-7.

8. Ashouri Moghaddam A, Radafshar G, Jahandideh Y, Kakaei N. Clinical Evaluation of Effects of Local Application of Aloe vera Gel as an Adjunct to Scaling and Root Planning in Patients with Chronic Periodontitis. J Dent (Shiraz, Iran). 2017;18(3):165-172.

http://www.ncbi.nlm.nih.gov/pubmed/29034 270.

9. Singh $P$, Jain $M$, Saxena $V$, Sharva $V$, Boddun M, Jain N. Evaluation of local delivery system containing $80 \%$ aloe vera gel used as an adjunct to scaling and root planning in chronic periodontitis: A clinical study. Dent Oral Maxillofac Res. 2019;5(4):1-5. doi:10.15761/domr.1000309.

10. Heng HC, Zulfakar MH, Ng PY. Pharmaceutical applications of Aloe vera. Indones J Pharm. 2018;29(3):101-116. doi:10.14499/indonesianjpharm29iss3pp10 1.

11. Virdi H, Jain S, Sharma S. Effect of locally delivered aloe vera gel as an adjunct to scaling and root planing in the treatment of chronic periodontitis: A clinical study. Indian J Oral Sci. 2012;3(2):84. doi:10.4103/0976-
6944.106460.

12. Bhat G, Kudva P, Dodwad V. Aloe vera: Nature's soothing healer to periodontal disease. J Indian Soc Periodontol. 2011;15(3):205-209. doi:10.4103/0972$124 X .85661$.

13. Hermanto NR, Syaify A, Sudibyo. Pengaruh Aplikasi Gel Aloe Vera Sebagai Bahan Tambahan Scaling Dan Root Planing Terhadap Penyembuhan Jaringan Periodontal Pada Perawatan Periodontitis Kronis. J Kedokt Gigi. 2015;6(3):307-314.

14. Shetty S V., Patil AK, Ganeshkar S V. Assessment of acid phosphatase and alkaline phosphatase in gingival crevicular fluid in growing and adult orthodontic patients: An in vivo study. J Indian Orthod Soc. $2015 ; 49(1): 10-14$. doi:10.4103/03015742.158627.

15. Sunao Uehera $\mathrm{H}$ ito et al. Relationship between bone-type alkaline phosphatase levels in gingival crevicular fluid and clinical parameters during supportive periodontal therapy. 2018:26-34.

16. Hajishengallis G. Immunomicrobial pathogenesis of periodontitis: Keystones, pathobionts, and host response. Trends Immunol. 2014;35(1):3-11. doi:10.1016/j.it.2013.09.001.

17. Serio FG, Duncan TB. The Pathogenesis and Treatment of Periodontal Disease. 2015.

18. Deepika V, Vishnu Priya V, Bedre A, Harsha L. Salivary AST, ALP and CK levels in patients with periodontitis. $J$ Pharm Sci Res. 2015;7(6):341-343 